音声言語医学 $55: 31-34,2014$

症例

\title{
歌手の喉頭ジストニア
}

一歌唱者の痤攣性発声障害——

\author{
小林 武夫 ${ }^{1)}$ 熊田 $\quad$ 政信 ${ }^{2} \quad$ 石毛美代子1) \\ 大森 蕗恵 ${ }^{1)}$ 望月 絢子1 ${ }^{1}$
}

\begin{abstract}
要 約：歌唱を職業とする者に, 歌唱時においてのみ見られる症攣性発声障害を「歌手の喉 頭ジストニア (singer's laryngeal dystonia)」と名づけた。痤攣性発声障害の一亜形である. 通常の会話は問題がない. 本症の発症前に過剩な発声訓練を行っていない. 4 例は第 1 例（女 性 31 歳）ソプラノ, ポピュラー, 第 2 例（女性 28 歳）ロック, 第 3 例（男性 40 歳）バリトン, 第 4 例（男性 46 歳）バリトンで, 第 4 例のみが外転型㾏攣性発声障害で, 他の 3 例は内転型 である。内転型は歌唱時に声がつまり, 高音の発声障害, 声域の短縮, ビブラートの生成が困 難となる，外転型では，無声子音に続く母音発声が無声化する。治療は，内転型はボッリヌス トキシンの少量頻回の声帯内注射が有効である，外転型では，後筋にボッリヌストキシンを注 射する.
\end{abstract}

索引用語：歌手, 歌唱, 痤攣性発声障害, ボツリヌストキシン, ジストニア

\section{Laryngeal Dystonia in Professional Singers}

Takeo Kobayashi ${ }^{1}$, Masanobu Kumada ${ }^{2}$, Miyoko Ishige ${ }^{1)}$, Fukie Oomori ${ }^{1)}$ and Ayako Mochizuki ${ }^{1)}$

\begin{abstract}
We report on four patients, all professional singers, presenting with spasmodic dysphonia. This condition has not been described in Japan. All four patients had not undergone excessive vocal practice. They demonstrated characteristics of adductor type dysphonia (3 cases) and abductor type dysphonia ( 1 case) while singing. Botulinum toxin was injected into the laryngeal muscles successfully. We recommend frequent, low-dose injections for adductor spasmodic dysphonia.
\end{abstract}

Key words: singer, singing, spasmodic dystonia, botulinum toxin, laryngeal dystonia

\section{はじめに}

職業に関係するジストニアとして, タイピスト・速 記者の書痤, 楽器演奏家に見られる pianist's hand (cramp), violinist's hand (cramp), 管楽器演奏者の embouchure ジストニアがある. embouchure は口唇 痓とも呼ばれる. 音楽家のジストニアの科学的研究は, 近年, 音楽家と生理学者の共同研究が行われるように

帝京大学ちば総合医療センター耳鼻咽喉科 ${ }^{11}$ ： テ299-0111 千葉県市原市姉崎 3426-3

耳鼻咽喉科クマダ・クリニック ${ }^{2)}$ ：干106-0031 東京都港区西麻布 4-2-6 エルファーストビル 3F

${ }^{11}$ Department of Otorhinolaryngology, Teikyo University Chiba Medical Center: Anesaki 3426-3, Ichihara, Chiba 299-0111, Japan

${ }^{2}$ Kumada ENT Clinic: Nishiazabu 4-2-6, Minato-ku, Tokyo 106-1031, Japan

2013 年 9 月 4 日受稿 2013 年 10 月 24 日受理 
なり, ギター演奏が盛んなスペインでは「テラッサ芸 術生理学医学研究所 Institut de Fisiologia i Medicina de L'Art-Terassa」が設立された ${ }^{1)}$ 。一方，歌唱の際 の喉頭ジストニアについては成書にも記載が少なく, Chitkara ${ }^{2)}$ の症例報告があるのみである。われわれは， 歌唱を職業とする人に，歌唱時においてのみ発現する 痤攣性発声障害をみつけたので歌手の喉頭ジストニア と名づけ発表する。

\section{症例}

当科において過去 20 年間（1993～2012 年）に計 373 症例の痤攣性発声障害に治療を行った。この間に 4 例の歌手の喉頭ジストニアを治療した。いずれもプ ロないしセミプロの歌手で, クラシック歌曲 2 例（男 性 2 例), クラシックとポピュラーの両方（女性 1 例), ロック（女性 1 例）である。男性の一人は外転型痤攣 性発声障害で, この例は, 症例報告をしたが3)，本稿 ではその後の経過を追加して略述する。他の 3 例は, 内転型痓攣性発声障害である。年齢は初診時年齢であ る

症例 $1 ： 31$ 歳女性, クラシック (ソプラノ)・ポピュ ラー歌手

初診時 4 年前より歌唱時に声がつまる。通常の会話 では問題がない。手術を受けることを勧められたが, 歌手の活動は不可能であると説明を受け，手術を受け ていない，外国でレッスンを受けたりするが，過剩な 練習はしていない，最近，話声位が低くなり，ときに 声が震えることがある。ボッリ又ストキシン（以下 BT と略す) を 2.5 単位両声带に注射したところ, 嗄 声が生じたので, 次回は量を減じて 1 単位を同様に注 射して, 発声は楽になった。 その後, 子育てのため仕 事を休止し，治療は中止している.

\begin{tabular}{|c|c|}
\hline 治療日 & BT 注射量 \\
\hline 2006. 3.25 & 2.5 単位（右）で発声が楽になった \\
\hline 4. 7 & 2.5 単位（右） \\
\hline 4.22 & 2.5 単位（右） 2.5 単位（左） \\
\hline 9. 6 & 2.5 単位（右） 2.5 単位（左） \\
\hline 10. 7 & 2.5 単位（右） 2.5 単位（左） \\
\hline 2007. 3.17 & 2.5 単位（右） 2.5 単位（左） \\
\hline 6. 3 & 2.5 単位（右） 2.5 単位（左） \\
\hline 9.15 & 2.5 単位（右） 2.5 単位（左） \\
\hline 2008. 1.12 & 2.0 単位（右） 2.5 単位（左） \\
\hline 3.22 & 2.5 単位（右） 2.5 単位（左） \\
\hline 6.21 & 2.5 単位（右） 2.5 単位（左） \\
\hline 9.13 & 2.5 単位（右） 2.5 単位（左） \\
\hline
\end{tabular}

診断：歌唱時の内転型㾏攣性発声障害.

症例 $2: 28$ 歳女性, ロック歌手

初診時半年前から，声がつまり歌えなくなった，通 常の会話は問題がない. 声の乱用も過剩な発声練習も ない. 表 1 のごとく BT 注射を頻回に受けつつロック の舞台はこなしていたが, 転職のため治療を中断した。

診断：歌唱時の内転型痤攣性発声障害.

症例 3:40 歳男性, クラシック歌手バリトン

23 歳のときに, 歌唱時にのどの違和感を生じ声が つまった。高音が出なくなりビブラートも出づらく なった。これが進行したので，リサイタル活動は中止 した．声の乱用や過剩な発声はない，高校の音楽教師 の仕事は, 何とか続けている。通常会話は問題ない. 治療として, 東洋医学 (ハリ, 気功), 催眠療法, 挙 句は除霊祈䘠まで受けた。

当科で BT 治療を行った。表 2 のごとく 1 回に注射 する BT の量を少なくして, 頻回に（年 4 8 回）注 射をしている，持続発声母音では，低音・高音とも声 帯の過内転は見られない，また，前回の注射との間隔 が短いため, 各注射前の喉頭ストロボで声带の振動が floppy（振幅が大きく，波動が小さい）という所見が 見られる. floppy な声帯振動は, BT 注射後効果があ るときに，一般的に見られる現象である。経過を追う と歌唱は劣化傾向にある。仕事は, 教育現場の仕事か ら，一時管理職に転換したが，最近現場に復帰した。

罹患前の声域は $\mathrm{E}_{2} \sim \mathrm{A}_{4}$ (話声位 $\mathrm{B}_{2}$ ), 罹患後の声 域は $\mathrm{F}_{2} \sim \mathrm{C}_{4}$ （話声位 $\mathrm{A}_{2}$ ）である。声質は変化し，実

表 2 症例 3 の BT 治療

\begin{tabular}{ccc}
\hline 年 & 回数 & 1 回のBT 量 $($ 単位 $)$ \\
\hline 1995 & 2 & 2.5 \\
1996 & 7 & $2.0 \sim 2.5$ \\
1997 & 4 & $1.2 \sim 2.0$ \\
1998 & 5 & $1.5 \sim 2.0$ \\
1999 & 5 & $1.5 \sim 2.0$ \\
2000 & 7 & $1.0 \sim 2.0$ \\
2001 & 5 & $1.0 \sim 1.5$ \\
2002 & 6 & $1.0 \sim 2.0$ \\
2003 & 5 & $1.0 \sim 1.5$ \\
2004 & 6 & $0.8 \sim 1.0$ \\
2005 & 7 & 0.8 \\
2006 & 7 & $0.5 \sim 0.8$ \\
2007 & 8 & $0.05 \sim 1.0$ \\
2008 & 5 & 0.75 \\
2009 & 6 & $0.5 \sim 0.75$ \\
2010 & 6 & 0.5 \\
2011 & 6 & $0.25 \sim 0.5$ \\
2012 & 5 & 0.5 \\
\hline
\end{tabular}


地の歌唱指導には困難を感じている.

診断：歌唱時の内転型痓攣性発声障害.

症例 4:46 歳男性, バリトン歌手

初診時 3 年前より原因なく声が続かなくなってき た．本人が「オートバイのクラッチがかからなくなっ た状態」「気流が声にならない」と表現。過剩な発声 訓練はない, いくつかの病院を訪れ, 異常なし, 重症 筋無力症，心因性疾患といわれている。声が出ないの でプロとしてのリサイタル活動は中止していた，診察 すると，無声子音に続く母音の無声化があった，音階 発声では高音が出ない，最長発声持続時間（/a:/) は 15 秒。治療として，両側後筋にBTを 5 単位ずつ注 射して声の改善を見た。「クラッチは $60 \%$ かかった」 と表現した。最長発声持続時間（/a:/）は19秒に改 善した。本症例では確認していないが，一般に後筋内 注射後, 声带の外転制限（外転可動域制限や外転動作 の遅れ）が見られる。そのことにより，無声子音に後 続する母音の無声化や声带振動の立ち上がりの遅れと いった外転型に特徵的な所見が消失ないし抑制され る。その後も，後筋に注射をして様子を見ているが， 1 回の注射でかなり長く効果がある。最近は調子良い ときに少人数の前でリサイタルを行っている.

診断：歌唱時の外転型痤尜性発声障害.

\section{考察}

\section{1 . 本疾患の名称}

歌手に見られた痤攣性発声障害とすると, 少し説明 不足である，通常の会話では問題がないが, 歌唱動作 で特異的に(task specific)引き起こされる状態なので, 通常の痓攣性発声障害とは独立した「歌手の病攣性発 声障害」とした，内転型，外転型をまとめて「歌手の 喉頭ジストニア (singer's laryngeal dystonia) と呼ぶ のがよいと思われる。

\section{2. 疾患の発現}

1 ） ジストニアの特徵として, 特異的な動作 (task) で運動異常が発現し増悪する。本稿での主題では, 歌 手が歌唱という動作の際にのみ声帯運動が障害され る。通常会話では異常は起きない，通常会話と歌唱で は錐体外路系レベルでの喉頭調带が異なるものと考元 られる。な拉，最近の国外の論文で 1）競売人 $\left.{ }^{41} ， 2\right)$ 宗教者の祈䘠発声時 ${ }^{5}$ ，3）一般人の通常会話時6) に起 こるジストニアが散見される。それらは，発声時に発 現するが，異常運動の発現は oro-mandibular（口顎） 部であり，声帯での声の生成は正常である。歌手の oro-mandibnlar dystonia の報告は見られない.
2) 楽器演奏家 (pianist's hand, violinist's hand, embouchure）のジストニアでは，遺伝，性格（完璧 主義者), 不安などの心理が認められ, 男性に多いと いわれる。歌手の喉頭ジストニアでは女性が多い22. 楽器演奏家のジストニアでは, 最も大きな発現要因は, 手, 腕, 指, 口唇の精密で迅速な運動, それの過度な 反復練習である，そのため，素人でなくプロの演奏家 で，ある程度の年季を経た者に見られる。歌手の喉頭 ジストニアではこのような傾向はない，自分自身の体 の一部である喉頭を楽器として使う歌唱発声について は，ピアノやギターを使う場合に比べ習熟度の次元が 少し低くても可能となるのかもしれない，局所性ジス トニア（pianist's hand）に悩んだロベルト・シュー マンは, 1 日 7 時間以上も激しいピアノ練習を行った という ${ }^{7,8)}$. 声楽家ではこのような長時間の練習を行 うことはない，せいぜい 3 時間程度の練習をすると思 われ，これ以上は喉頭の負担になる，われわれの症例 では過度な発声訓練は認められなかった。心理的要因 も認められていない。歌手の喉頭ジストニアは, 現時 点では原因不明である。

\section{3. 性差}

楽器演奏家のジストニアは男性に多いが9)，歌手は Chitkara ${ }^{2)}$ とわれわれの例を併せると，内転型は男性 2 例, 女性 5 例である。外転型は男性 1 例, 女性 1 例 である。

\section{4. 発現する痙攣性発声障害の型}

内転型と外転型がある。前者が多い.

\section{5. 症状}

通常の会話では症状は発現しない, 内転型では, 低 音から高音に上げていくと声がつまってくる，進行す ると高い声が出しにくくなり，声域は狭くなる，外転 型では，無声子音に続く母音発声が困難となり，ビブ ラートがかからず，声に艶がなくなる，発声持続時間 が短縮する.

\section{6. 声のジャンル}

どの声種についても起こりうる。ロック歌手では, それほど不都合な事態は生じなかったので，コンサー トを続けた。邦楽に扔いて，喉頭ジストニアが起きる かどうかは報告が見当たらない，早いパッセージ，音 程が著しく上下するような複雑な歌唱は邦楽には見ら れないのも，邦楽で喉頭ジストニアの報告が見られな い理由かもしれない.今後の研究課題である.

\section{7. 歌手としての将来}

病前の音楽活動に復帰することは, Chitkara ${ }^{2)}$ の例 およびわれわれの例を見ても困難がある. 


\section{8. 治療}

1 ) 音声訓練

Chitkara $^{2)}$ の報告では，全 5 例に音声訓練を行うこ とが試みられているが, 効果がなかっだ2。 今回の報 告例では音声訓練を行っていない.

2 ) botulinum toxin (BT) 注射10)

(1) BT の種類

当科で使用してきた BT は Botox（商品名, 米国製) と Dysport（商品名，米国製）とある。この両者は, 同一単位でも効果に差がある，検定法に差があるから で, Botoxのほうが同一単位でも Dysportより約 2 割 程度強力という感じを受ける。効果の比較については 統一見解はない.

今回症例 1-3 は Dysport を, 症例 4 は, Botox を使 用した。

（2）内転型に対し

内転型の場合，われわれの第 2 例，第 3 例のように $\mathrm{BT}$ 注射が一番現実的である. 両例とも患者の声の状 態をその都度検討して BT の量を徐々に減じて注射し た。最終的に. BT 0.25〜1 単位となった。ただし， この場合は, 通常量のように長期間 (通常は 3 4 カ月) 効果が持続しないので, 頻回の注射が必要となる。こ の治療を行っているとき, Chitkara ${ }^{2)}$ の文献を発見し, 彼らがわれわれと同じく少量頻回の BT 注射を行って いることに気づいた。プロ歌手では，ごく微量な BT でも有効となることを自覚し, 自分で量を調節して注 射量を示唆してくる.

（3）外転型に対し

この場合は, 通常の病攣性発声障害の場合と同じ量 を行うことが必要である。

3 ）感覚トリック

ジストニアの特徵の一つが感覚トリックである, 発 声時に顔や澒に手を当てたり手を握ったりするだけ で，障害が軽減することがある。このようなことを患 者が経験する場合はこれを各人に工夫してもらう。こ のようなことを勘案すると，歌手が表情豊かに身振り 手振りを交えて歌うのは, 発声にも良い影響を与える のではないかと思われる.

\section{4 ) 手術}

通常の痤攣性発声障害に行うような手術は, 術後, 歌唱の声が変化するので行いにくい，今後の問題であ る.

\section{まと め}

音楽家のジストニアは, 器楽についての報告や研究 は多いが, 歌唱の際の喉頭ジストニアは海外での先行 文献が 1 つだけである。本稿は，本邦では最初の報告 と考える.

本症の発現には, 明確な要因は確定できないが, 楽 器演奏者のジストニアと違い, 過剩な習熟練習はない と思われる。治療としては，ボッリヌストキシンの声 帯内への少量注射を反復して行うことが一番現実的で ある、本症の発現機構や，最適な治療方法については さらなる研究の必要がある。

竹田数章（東京都）抢よび西浦美佐子（都城市）両先生の協 力に感謝する。

\section{文献}

1) Rosset i Llober J and Fabregas i Molas S: Musician's Dystonia, 私家版, バルセロナ, 2010.

（日本語訳）平 孝臣，堀内正浩監訳，NPO 法人ジストニ ア友の会訳：どうして弾けなくなるの?，音楽友の社，東 京, 2012 .

2) Chitkara A, Meyer T, Keidar A, et al: Singer's dystonia: First report of a variant of spasmodic dysphonia. Ann Otol Rhinol Laryngol, 115: 89-92, 2006.

3）小林武夫, 石毛美代子，一八瀬篤司：歌手にみられた外転 型痓攣性発声障害。喉頭, 25：12-14, 2013.

4) Scolding NJ, Smith SM, Sturman S, et al: Auctioneer's Jaw: a case of occupational oromandibular hemidystonia. Mov Disord, 10: 508-509, 1995.

5) Ilic TV, Pötter M, Holler I, et al: Praying-induced oromandibular dystonia. Mov Disord, 20: 385-386, 2005.

6) Moller E, Bakke M, Delager T, et al: Speaker's cramp: a new type of oromandibular dystonia. JADR/AADR General Meeting (On Line) ABS-3606, 2005.

7）平 孝臣, 堀内正浩監訳, NPO 法人ジストニア友の会訳： 第 1 章 音楽家のジストニアとは何か? 。どうして弾けな くなるの?, 音楽友の社, 東京, 12-14 頁, 2012 .

8）浅沼光太郎：音楽家のジストニア. ジストニアのすべて (梶 龍児編)，診断と治療社，東京，29-30 頁，2013.

9）平 孝臣，堀内正浩監訳， NPO 法人ジストニア友の会訳： 第 2 章 音楽家のジストニアとは。 どうして弾けなくなる の?, 音楽友の社, 東京, 19 頁, 2012 .

10）小林武夫, 大森蕗恵, 石毛美代子：喉頭ジストニア. ジス トニアのすべて (梶 龍児編), 診断と治療社, 東京, 24-28 頁, 2013. 